\title{
Three Cases of Acute Ketotic Diabetes Mellitus with Myocarditis: A Common Viral Origin?
}

\section{PHILIP GIBBS}

British Medical fournal, 1974, 3, 781-783

\section{Summary}

Focal electrocardiographic abnormalities have been noted in three young adults who developed acute diabetes after an illness bearing the hallmarks of a viral infection. The persistent $S-T$ and $T$ wave changes were inexplicable in terms of acute electrolyte imbalance or ischaemic heart disease and were ascribed to viral myocarditis. The significance of this is discussed.

\section{Introduction}

The transient electrocardiographic (E.C.G.) changes which accompany diabetic ketosis are well known though incompletely understood. They usually disappear within 24 hours of therapy and the commonest change is $S-T$ depression though the Q-T interval may be prolonged and abnormalities of the $T$ wave can also occur. In about half the cases there is disparity between the severity of the ketosis and the resultant E.C.G. abnormalities (Bellet and Dyer, 1937; Mantin and Wertman, 1947; Henderson, 1953).

Three young adults who developed acute diabetes had persistent E.C.G. abnormalities. After they were stabilized on insulin the E.C.G.s recorded in the supine position showed minor repolarization changes, and when the E.C.G. was repeated with the patient standing the focal changes were augmented (orthostatic E.C.G. reaction).

\section{Case 1}

This 25-year-old housewife was admitted on 14 March 1971 for stabilization of her acute diabetes six weeks after an acute illness with malaise, severe headache, proximal myalgia, and troublesome palpitations. She had undergone thyroidectomy for thyrotoxicosis in 1970 and had two children of normal birth weight. There was no family history of diabetes. When examined she was not anaemic though she was mildly dehydrated, and the pulse was basically regular with frequent premature beats. Heart sounds were normal and her blood pressure was $140 / 70$. Urinalysis showed $2 \%$ sugar and moderate ketonuria. She had mild leucopenia $\left(4,600 / \mathrm{mm}^{3}\right)$ with relative lymphocytosis, the chest $x$-ray picture confirmed normal cardiac size, her blood sugar was $262 \mathrm{mg} / 100 \mathrm{ml}$, her serum potassium was $3.3 \mathrm{mEa} / 1$., and the other electrolytes were normal. Viral antibody studies on paired sera for the Coxsackie group (complement fixation test), mumps, adenovirus, influenza $A$ and $B$ virus, parainfluenza 1 , mycoplasma and $Q$ fever showed no change. The E.C.G. (fig. la) 28 hours after admission showed bradycardia $(60 / \mathrm{min})$ with a prolonged Q-T interval of $0.48 \mathrm{sec}$ $\left(Q_{c}=0.4 \mathrm{sec}\right)$. There were still frequent atrial extrasystoles and deep asymmetrical $T$ wave inversion in V1-3, II, III, and aVF. When the record was repeated on 26 March (fig. 1b) the $T$ waves were flattened in the posterior leads and remained inverted in V1-3.

She was stabilized on a morning dose of 20 units of soluble insulin and 12 units of protamine zinc insulin injection. Her convalescence was stormy with frequent hypoglycaemia, and the myalgia and headaches continued for six months after discharge.

M.3 Unit, Manchester Royal Infirmary, Manchester M13 9WL PHILIP GIBBS, M.R.C.P., Medical Tutor

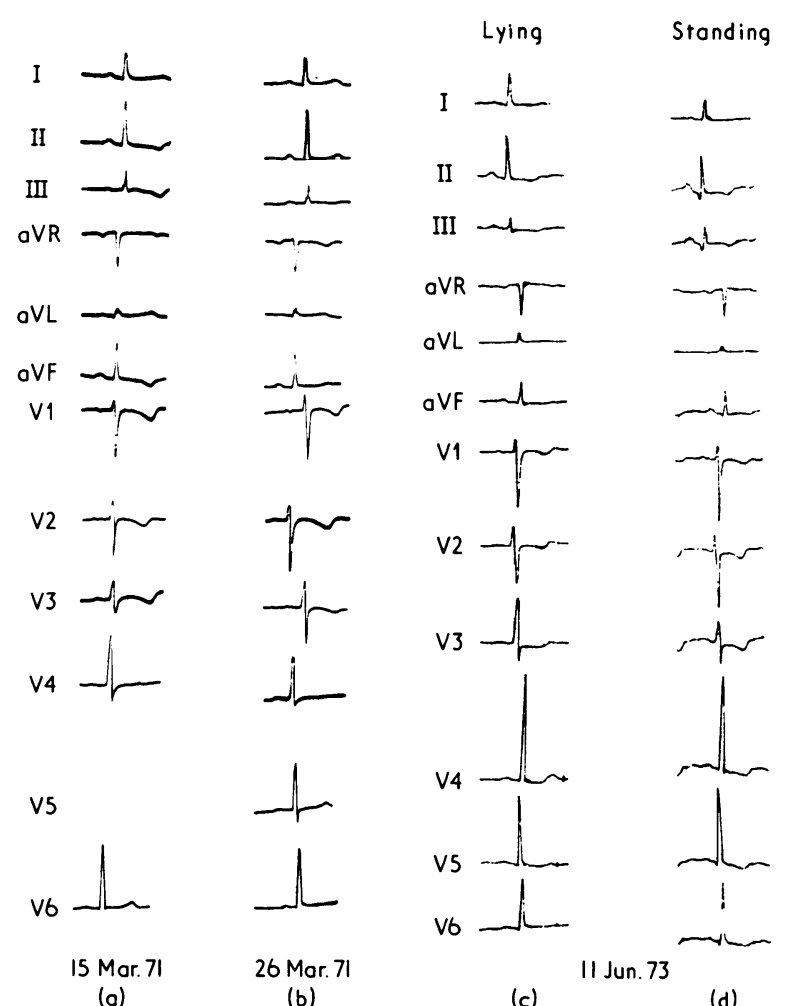

FIG. 1. Case 1.-Widespread T wave inversion on E.C.G. taken soon after admission (a) and less marked changes (b) after 11 days in hospital. In June 1973 (c) E.C.G. was still abnormal with marked orthostatic change (d) in inferior and anterior leads.

In April 1973 she was healthy and well controlled. A supine E.C.G. showed mild repolarization changes, which were greatly increased in the standing record (fig. lc and d) though the patient had no cardiac symptoms. Antimyocardial antibodies were present in serum at $1 / 16$ dilutions.

\section{Case 2}

This 31-year-old engineer was admitted with severe ketoacidosis on 8 March 1972 after five days of increasing headache, pyrexia, confusion, and leg weakness. Three days before admission he developed thirst and polyuria. He had no family history of diabetes. When examined he was a dehydrated, slim man with Kussmaul's respiration. He was flushed with sinus tachycardia $(130 / \mathrm{min})$ and his blood pressure was $95 / 50$. Heart sounds and cardiac size were normal. He was stuporose but there were no definite neurological signs. Urinalysis showed $2 \%$ glycosuria and gross ketonuria. His blood sugar was $640 \mathrm{mg} / 100 \mathrm{ml}$, and blood urea was $75 \mathrm{mg} / 100$ $\mathrm{ml}$, and his white cell count was $10,600 / \mathrm{mm}^{3}$. His electrolytes and chest $x$-ray picture were normal. He was treated with intravenous fluids, soluble insulin, and $120 \mathrm{mEa}$ of potassium chloride in the first 24 hours after admission. The next day he was still grossly confused, his blood pressure had risen to $120 / 80$, and his E.C.G. (fig. 2a) showed bradycardia $(50 / \mathrm{min})$ with prolonged Q-T interval of $0.52 \mathrm{sec}\left(Q T T_{c}=0.42 \mathrm{sec}\right)$. There was isoelectric $S-T$ take off with deep asymmetrical $T$ wave inversion in V1-4. He developed leucopenia (white cell count $3,000 / \mathrm{mm}^{3}$ ) with toxic granulation of leucocytes. An E.C.G. taken on 15 March 1972 showed S-T depression in leads II, III, and aVF with biphasic $T$ waves. There were residual $\mathrm{T}$ wave abnormalities in VI-4 (fig. $2 \mathrm{~b}$ ). Viral studies showed an antibody rise in convalescent serum for Coxsackie B, 


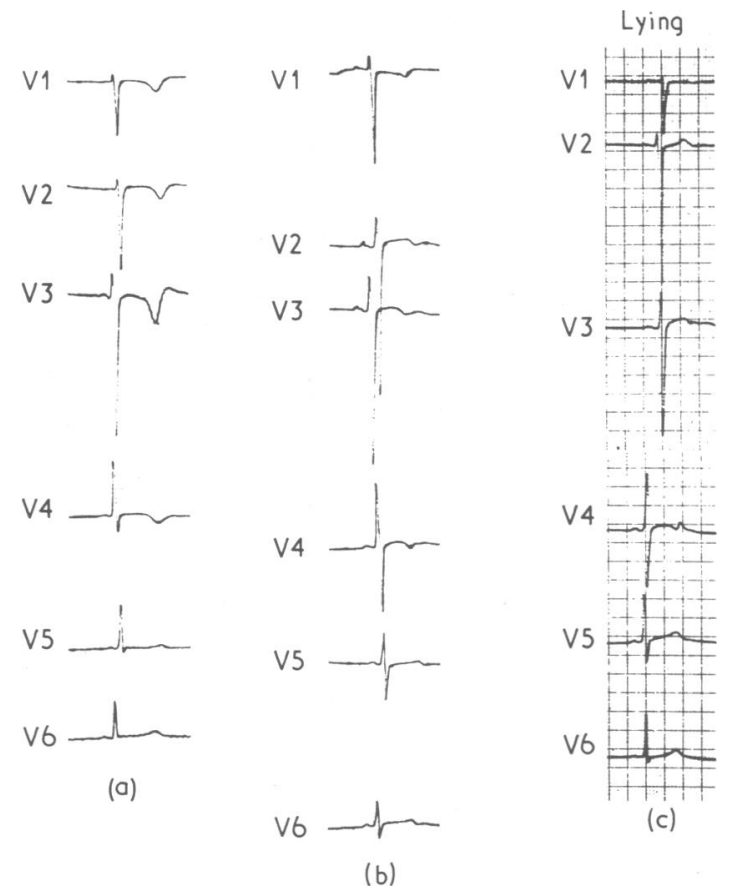

FIG. 2. Case 2.-Day after therapy began (9 March 1972) E.C.G. showed deep $T$ wave inversion over anteroseptal leads with a prolonged $Q-T$ interval (a). After stabilization on 15 March 1972 S-T and T wave changes persisted and in January 1973 S-T and $T$ wave changes, including an unusual biphasic $T$ wave in V4, were still present (c).

and $B_{5}$ virus of $>1 / 20$ dilutions, and the Coxsackie complement fixation test showed a non-specific rise. He recovered from the confusion in a week and was easily stabilized on a small morning dose of insulin lente. An E.C.G. in January 1973 showed unusual biphasic $\mathrm{T}$ waves in V3 and V4 with some orthostatic change (fig. 2c).

Coxsackie $B_{4}$ or $B_{5}$ virus may have caused the acute illness but the aetiology remained unproven.

\section{Case 3}

This 22-year-old butcher whose mother was an insulin-requiring diabetic suddenly developed malaise, headache, and myalgia in mid-December 1972. During the next week he noticed a maculopapular rash all over his body and had pain in both testicles, which became inflamed and swollen. By January the testicular pain and headache had improved, the myalgia remained, and he also notioed weight loss, thirst, and polyuria. When examined on
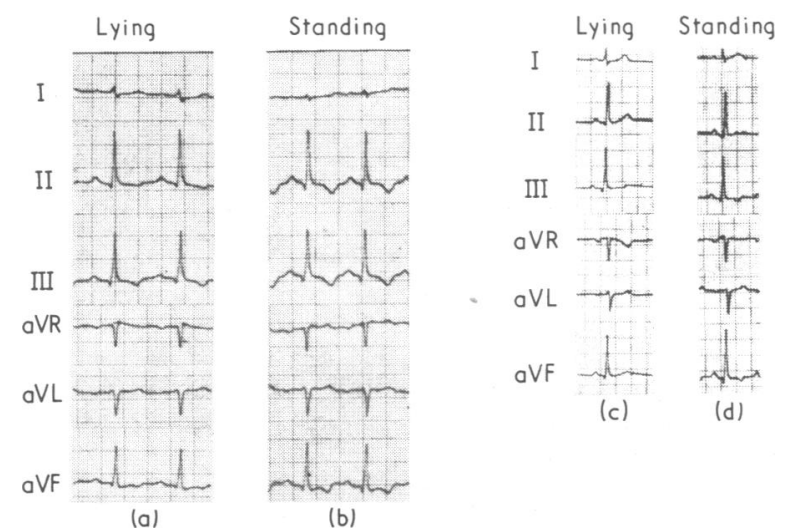
FIG. 3. Case 3.-E.C.G.s taken on 30 January 1973, ten days after admission.
Supine record similar to E.C.G. taken day after admission showing $T$ wave inversion in inferior leads (a). Standing E.C.G. shows marked increase in $T$ wave inversion (b). Three months later supine record shows flattened $T$ wave with S-T depression in lead III. Standing record shows marked $T$ wave inversion in leads III and aVF. $\mathrm{T}$ wave flattening also occurs in lead II (d).
20 January the rash was fading and weight loss was present. The pulse was regular, the heart sounds normal, and clinically there was no cardiomegaly. Both testes were still mildly tender. His blood pressure was $130 / 80$, and urinalysis showed glycosuria and moderate ketonuria. His blood sugar was $450 \mathrm{mg} / 100 \mathrm{ml}$ and his chest $x$-ray picture was normal and showed no cardiomegaly. Total serum globulin was $1.9 \mathrm{~g} / 100 \mathrm{ml}$ with $\mathrm{IgG} 380 \mathrm{mg} / 100 \mathrm{ml}$, IgM $56 \mathrm{mg} / 100 \mathrm{ml}$, and IgA $310 \mathrm{mg} / 100 \mathrm{ml}$. Viral culture was attempted unsuccessfully from throat swabs and paired sera showed no antibody rise for influenza $A$ and $B$, adenovirus, measles, or mumps $\mathrm{S}$ and $\mathrm{V}$ antibodies. The Coxsackie complement fixation test showed a non-specific change and Coxsackie $\mathrm{B}_{4}$ complementfixing antibodies were present in both specimens at 1/10 dilutions. An E.C.G. on 20 January 1973 showed $T$ wave inversion in lead III with biphasic $T$ waves with depressed S-T segments in leads II and aVF. There were flattened S-T segments in V4-6. An E.C.G. on 30 January 1973 showed a similar picture (fig. 3a) and there was marked orthostatic change in the affected leads (fig. 3b). He was stabilized on soluble insulin though when reviewed two months later he still had intermittent headaches and myalgia. His IgG was $730 \mathrm{mg} / 100 \mathrm{ml}$, IgM $49 \mathrm{mg} / 100 \mathrm{ml}$, and IgA 245 $\mathrm{mg} / 100 \mathrm{ml}$, and E.C.G.s (fig. $3 \mathrm{c}$ and d) showed an onthostatic reaction in leads III, aVF, and V4-6. By June 1973 he was well and the myalgia had ceased.

\section{Discussion}

These three young patients, who recovered good health, had clinical features of a viral illness before the onset of acute diabetes. Persistent focal E.C.G. changes were present which could not be explained by temporary electrolyte balance. There was no clinical evidence to suggest ischaemic heart disease though such a sequence of events is the commonest presentation of acute myocarditis (Bergstrom et al., 1970; Gerzen et al., 1972). Only the first patient had cardiac symptoms with frequent and troublesome palpitations. All three had complained of headache, lethargy, and muscular weakness during the acute illness which preceded the diabetes. Myalgia, often associated with viral myocarditis (Lewes and Rainford, 1970), was present in cases 1 and 3. The encephalitis-like illness (case 2) and orchitis (case 3) also suggested a viral cause for the initial illness. In cases 1 and 3 the period between the illness and admission made viral isolation and antibody studies impossible, and in case 2 the antibody rise though suggestive was inconclusive. The acquired immunodeficiency with low IgG levels (Hobbs, 1968) as observed in case 3 may be another adverse factor. Viral culture from cerebrospinal fluid (case 2) and from a testicular biopsy specimen (case 3 ) might have been rewarding.

The commonest E.C.G. features of acute myocarditis are inverted, flat, or biphasic $T$ waves and $S-T$ elevation, the QRS complex usually being spared (Gerzen et al., 1972). Residual E.C.G. abnormalities were seen in only two out of 45 of the follow-up cases of Gerzen et al. (1972), but the orthostatic E.C.G. reaction was present in 13 cases and compared well with the original changes. The orthostatic change was abolished by beta-adrenergic blockade with intravenous propranolol, raising the possibility that some of the E.C.G. changes seen in diabetic ketosis may be caused by raised blood catecholamines (Christensen, 1974) besides electrolyte imbalance acting as stress phenomena on a heart with just such a benign myocardial lesion.

Though juvenile diabetes is certainly associated with other autoimmune disorders (Carpenter et al., 1964; Ungar et al., 1968; Irvine et al., 1970) there has been a strong clinical impression that infection plays an important role at the onset (Cole, 1934; Brown, 1956). Three of Cole's cases followed mumps, and others have confirmed this finding (Kremer, 1947; Melin and Ursing, 1958). Infection with encephalomyocarditis virus (Craighead and Stienke, 1961) and Coxsackie group $B_{4}$ virus (Coleman et al., 1973) have produced experimental diabetes in animals, and human diabetes is commoner in the colder months when viral infections are more prevalent (Adams, 1926; Gamble and Taylor, 1969). The Coxsackie 
$B_{4}$ virus in particular seems implicated at the onset of juvenile diabetes (Gamble et al., 1969). Though a viral aetiology is unproven these three clinical cases with a myocardial lesion are interesting and lend suppont to sudies suggesting that viral infection may predispose to juvenile diabetes.

I am grateful to Dr. Samuel Oleesky for his help and advice and thank him and Dr. Richard Stone for allowing me to study their patients. The department of medical illustration, Manchester Royal Infirmary, provided the photographs of the E.C.G.s.
Bellet, S., and Dyer, W. W. (1937). American Heart fournal, 13, 72.

Bergstrom, K., et al. (1970). Scandinavian fournal of Infectious Diseases, 2, 7 Brown, E. E. (1956). Archives of Paediatrics, 73, 191.

Carpenter, C. C., et al. (1964). Medicine, 43, 153.

Christensen, N. J. (1974). Diabetes, 23, 1.

Cole, L. (1934). Lancet, $1,947$.

Coleman, T. J., Gamble, D. R., and Taylor, K. W. (1973). British Medical Fournal, 3, 25.

Craighead, J. E., and Stienke, J. (1971). American fournal of Pathology, 63, 119 .

Gamble, D. R., et al. (1969). British Medical fournal, 3, 627

Gamble, D. R., and Taylor, K. W. (1969). British Medical fournal, 3, 631. Gerzen, P., et al. (1972). British Heart fournal, 34, 575.

Henderson, C. B. (1953). British Heart fournal, 15, 87.

Hobbs, J. R. (1968). Proceedings of the Royal Society of Medicine, 61, 883.

Irvine, W. J., et al. (1970). Lancet, 11, 163 .

Kremer, H. U. (1947). American fournal of Medicine, 3, 257.

Lewes, D., and Rainford, D. J. (1970). Lancet, 1, 520.

Martin, H. E., and Wertman, M. (1947). American Heart fournal, 34, 646.

Melin, K., and Ursing, B. (1958). Nordisk Medicin, 60, 1715.

Ungar, B., et al. (1968). Lancet, 2, 415.

\section{PRELIMINARY COMMUNICATIONS}

\section{Cervical Plasma Cell Population in Infertile Patients}

\author{
R. B. HUTCHESON, T. D. ANDERSON, \\ E. J. HOLBOROW
}

British Medical fournal, 1974, 3, 783-784

\begin{abstract}
Summary
Cervical biopsy specimens were obtained from 50 controls and 50 women attending an infertility clinic. Sections were cut and stained, by a direct immunofluorescent technique, with fluorescein-labelled sheep antihuman IgA, antihuman IgM, and antihuman IgG in an attempt to show a difference between the two groups. A significant increase in the number of plasma cells containing IgA was found in many of those infertile women in whom no other abnormality could be detected.
\end{abstract}

\section{Introduction}

Much of the recent literature pertaining to immunological infertility revolves around the study of the male reproductive system, in particular, the origin and nature of antigens associated with spermatozoa and seminal plasma (Shulman, 1972). Others have concentrated on the problem of the significance of antibodies found in the cervical mucus (Parish and Ward, 1968).

The decision to examine the cervical tissue itself in an attempt to show an alteration in cell population or structure in immunologically infertile patients stemmed from two important observations. Firstly, it has been well established that the secretory IgA system provides a first line of defence for the mucosal linings of the body. This has been best illustrated in the bowel (fig. 1) and the respiratory systems but it has

M.R.C. Unit, Canadian Red Cross Memorial Hospital, Taplow

R. B. HUTCHESON, M.R.C.o.G., Research Registrar. (Present appointment: Senior Registrar, Obstetrics and Gynaecology Unit, Hammersmith Hospital, London.)

T. D. ANDERSON, F.R.C.s., M.R.c.o.G., Consultant Obstetrician and

E. J. HOLBOROW, M.D., Consultant Bacteriologist

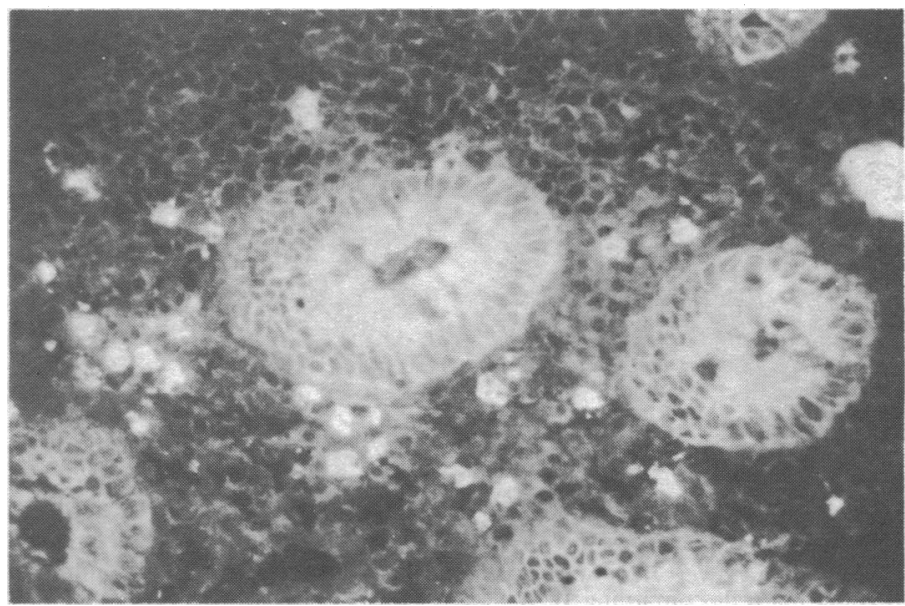

FIG. 1-High-power view of appendix stained with sheep antihuman fluorescein-labelled IgA showing plasma cells containing IgA near columnar epithelium.

also been shown that plasma cells containing IgA are to be found in many other organs of the body (Drayton et al., 1971). Secondly, it has been clearly shown that there is an increase in the number of plasma cells containing IgA in the cervices of women suffering from local infections such as candidiasis, gonorrhoea, and trichomonal vaginitis (Chipperfield and Evans, 1972).

These findings led to the postulation that spermatozoa in certain cases of infertility might produce a similar plasma cell reaction, to the detriment of the sperm.

\section{Method}

Using a hollow steel tube $6-\mathrm{cm}$ long and just over $3 \mathrm{~mm}$ in diameter with a sharp cutting edge at one end small but undamaged biopsy specimens were obtained from both endocervix and ectocervix. In the first instance the technique was carried out on specimens obtained at hysterectomy (fig. 2). This group subsequently provided the controls which were incorporated into the series. In the strictest sense these were not ideal as controls as, though there was no history of infentility recorded in the group, at least one of these patients might have developed a late secondary immunological infertility which had gone undiagnosed. A true control series would have been made up of a group of 